\title{
GEOMORPHIC LANDFORM DESIGN PRINCIPLES APPLIED TO AN ABANDONED COAL REFUSE PILE IN CENTRAL APPALACHIA ${ }^{1}$
}

\author{
Leslie C. Hopkinson ${ }^{2}$, Jeffrey T. Lorimer, Jeffrey R. Stevens, Harold Russell, Jennifer Hause, \\ John D. Quaranta, Paul F. Ziemkiewicz
}

\begin{abstract}
Geomorphic landform design is a reclamation technique that may offer opportunities to improve aspects of mine reclamation in Central Appalachia. The design approach is based on constructing a steady-state, mature landform condition and takes into account the long-term climatic conditions, soil types, terrain grade, and vegetation. Geomorphic reclamation has been applied successfully in semiarid regions but has not yet been applied in Central Appalachia. This work describes a demonstration study where geomorphic landforming techniques are being applied to a coarse coal refuse pile in southern West Virginia, USA. The reclamation design includes four geomorphic watersheds that radially drain runoff from the pile. Each watershed has one central draining channel and incorporates compound slope profiles similarly to naturally eroded slopes. Planar slopes were also included to maintain the impacted area. The intent is to reduce infiltration rates which will decrease water quality treatment costs at the site. The excavation cut and fill volumes balanced to approximately $250,000 \mathrm{yd}^{3}$. This volume is comparable to those of more conventional refuse pile reclamation designs. If proven successful then this technique can be part of a cost-effective solution to improve water quality at active and future refuse facilities, abandoned mine lands, bond forfeiture sites, landfills, and major earthmoving activities within the region.
\end{abstract}

Additional Key Words: demonstration site, channel design, short paper fiber

${ }^{1}$ Paper presented at the 2017 National Meeting of the American Society of Mining and Reclamation, Morgantown, WV What's Next for Reclamation April 9-13, 2017. R.I. Barnhisel (Ed.) Published by ASMR, 1305 Weathervane, Champaign, IL 61821.

${ }^{2}$ Leslie C. Hopkinson is an Associate Professor of Civil and Environmental Engineering, West Virginia University, Morgantown, WV 26506; Jeffrey T. Lorimer is a former Graduate Research Assistant, Civil and Environmental Engineering, West Virginia University, Morgantown, WV 26506; Jeffrey R. Stevens is a former Graduate Research Assistant, Civil and Environmental Engineering, West Virginia University, Morgantown, WV 26506; Harold Russell is a Graduate Research Assistant, Civil and Environmental Engineering, West Virginia University, Morgantown, WV 26506; Jennifer Hause is a Program Coordinator, West Virginia Water Research Institute, Morgantown, WV 26506; John D. Quaranta is an Associate Professor of Civil and Environmental Engineering, West Virginia University, Morgantown, WV 26506; and Paul F. Ziemkiewicz is Director, West Virginia Water Research Institute, Morgantown, WV 26506.

Journal American Society of Mining and Reclamation, 2017 Volume 6, Issue 2 pp 19-36

DOI: http://doi.org/10.21000/JASMR17020019 


\section{Introduction}

Geomorphic landforming is a watershed-scale reclamation strategy used to design and construct earthen structures while balancing erosive and resistive forces. The intent is, in part, to mimic mature landforms by including dendritic channel networks and compound slope profiles (Hancock et al., 2003; Toy and Chuse, 2004; Schor and Gray, 2007; Eckels and Bugosh, 2010). The reclamation tool is slowly gaining acceptance because the principles have been applied to mine sites where watershed performance has been monitored and government agencies have shown interest (Schor and Gray, 2007). Recent research reported benefits associated with initial reclamation project expenditures, ongoing maintenance, constructability, and government acceptance (e.g., Robson et al., 2009; Measles and Bugosh, 2007; Martín-Duque et al., 2010; Eckels and Bugosh, 2010).

Geomorphic designs have yet to be implemented in the eastern coal-producing regions of the United States due to region-specific challenges. Michael et al. (2010) were among the first to identify these challenges in Central Appalachia. For example, both state and Federal mining regulations require conventional planar-benched sloped designs. There is a regulatory emphasis on minimizing stream burial, perceived cost is high, and the steep youthful terrain is difficult to work in (Michael et al., 2010). Continued research has shown that difficulties associated with steep slopes and stability (both channel and hillslope) are valid when minimizing the area of impact (DePriest et al., 2015), and methods have been developed to overcome some of these challenges (e.g., Sears et al. 2014; Michael et al., 2015; DePriest et al., 2015).

This work presents a demonstration reclamation design involving geomorphic principles for an abandoned coarse coal refuse pile in southern West Virginia. The field site has been abandoned since 1999 and is currently the financial responsibility of the State of West Virginia, Department of Environmental Protection, which has annually expended more than $\$ 200,000$ for acidic mine water treatment (Ward, 2001). One objective of this work was to alter the surface drainage pattern using geomorphic reclamation techniques to minimize infiltration into the pile. The intent was to reduce contact time of stormflow within the pile to promote long-term reduction water treatment

and maintenance costs. As such, the following features were desired in the final design: i) apply geomorphic landforming principles; ii) reduce stormwater infiltration; iii) segregate stormwater 
and groundwater flows; iv) minimize earth moving quantities; and v) minimize soil borrow material.

\section{$\underline{\text { Methods }}$}

Methods used to design the geomorphic reclamation plan are described in the following sections.

Field site

The Royal Scot refuse facility is a 47 -acre $\left(0.19 \mathrm{~km}^{2}\right)$ coal refuse pile in Greenbrier County, WV, USA $\left(38^{\circ} 00^{\prime} 41^{\prime \prime} \mathrm{N}, 80^{\circ} 36^{\prime} 08^{\prime \prime} \mathrm{W}\right)$ (Fig. 1). The site is a ridge-top reclamation $(3,500$ $3,760 \mathrm{ft}$.), is located within a larger mine permit operation, and is located in the Central Appalachia ecoregion (i.e., USEPA, 2013). An active permit exists along the north and west boundaries, and forest exists along the south and east boundaries (Fig. 2). The ridge-top location is unique because traditionally coal refuse piles are located in valley bottoms near process and loading facilities.

The Royal Scot Minerals Inc. mining permit was revoked on April 21, 1999, and the refuse facility has remained inactive through the present day (N. Parks, personal communication, 2015). Some surface slopes of the landmass are in excess of $26.56^{\circ}$ above horizontal, and little to no vegetation is present. The combination of steep slopes and barren topography led to erosion (i.e., gullies) (Fig. 3). Stevens (2016) characterized the coarse coal refuse as a 'poorly graded sand with gravel' with a hydraulic conductivity of $0.0028 \mathrm{ft} /$ day $\left(10^{-6} \mathrm{~cm} / \mathrm{s}\right)$.

To comply with the National Pollution and Discharge Elimination System (NPDES) permit, groundwater and stormwater are collected and directed to the water treatment ponds (Fig. 2) prior to discharging from the site (N. Parks, personal communication, 2015). The treatment ponds are routinely dredged of sediment to maintain effective treatment capability, and the waste material is disposed of in the on-site sludge pit area (Fig. 2).

Stormwater runoff was historically routed to the pond positioned at the south of the pile (Fig. 2), but this pond is not currently used due to seepage. The pond was constructed with a permeable underdrain but has since clogged preventing discharge flow. The existing pond is 1.67

acres in top area. Approximately 35,000 $\mathrm{yd}^{3}$ of material were removed from the pond in 2012, lowering the invert elevation to $3598 \mathrm{ft}$. Excavation procedures encountered competent foundation rock strata at $3598 \mathrm{ft}$. The rock foundation is believed to be fractured and jointed and the source of the seepage. 


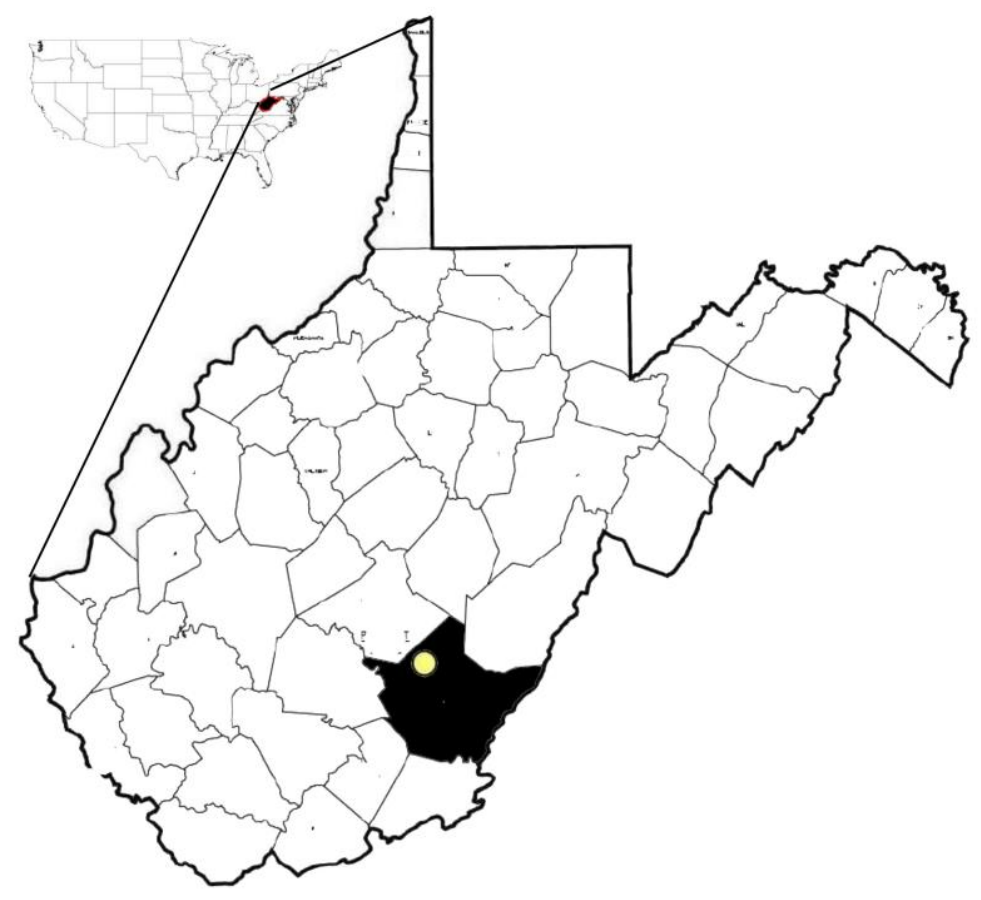

Figure 1. Project location (yellow marker) in Greenbrier County, West Virginia, USA (shaded black).

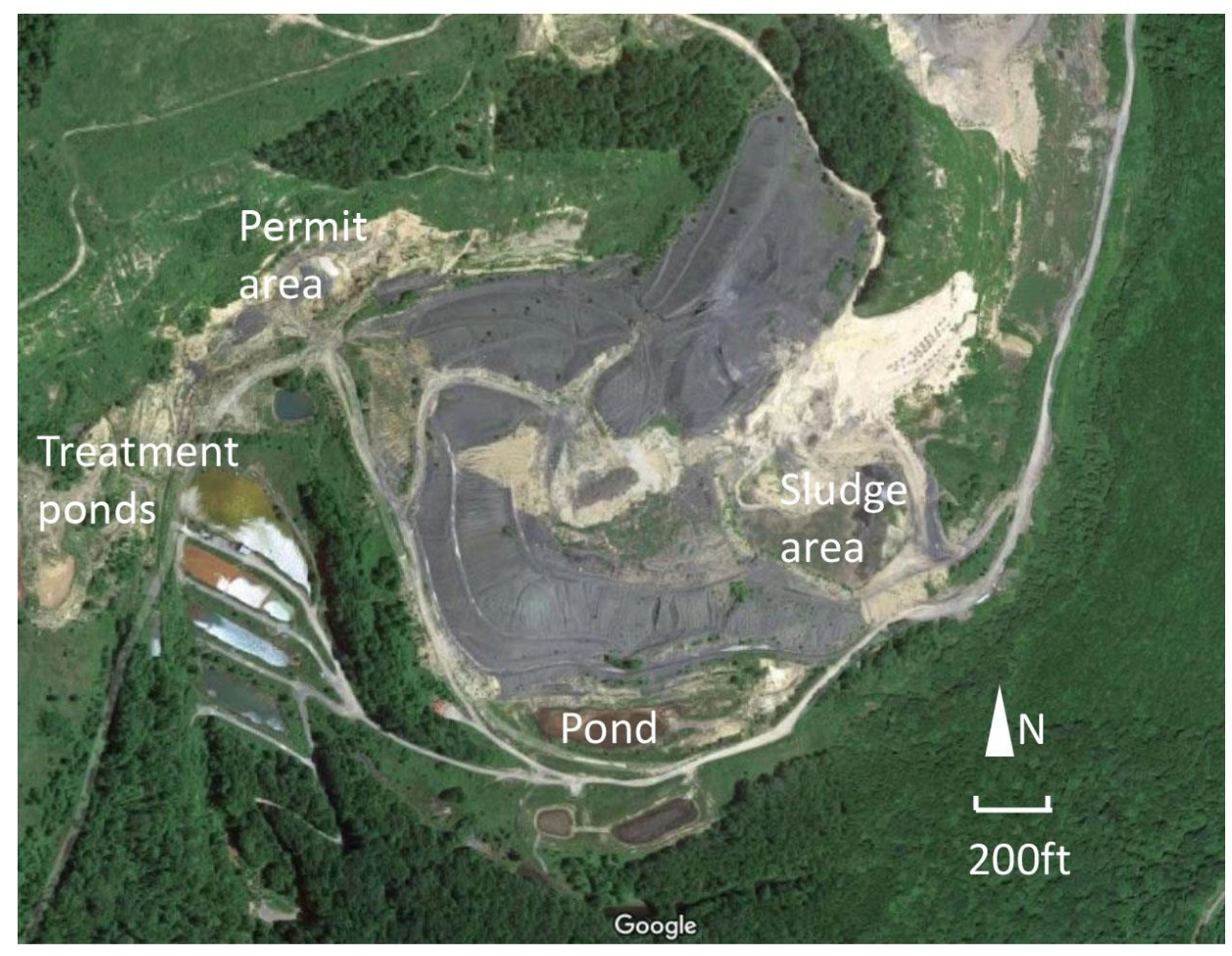

Figure 2. Aerial image of coal refuse facility showing the main pile, sludge pit area, existing pond, AMD treatment ponds, and active permit area. 


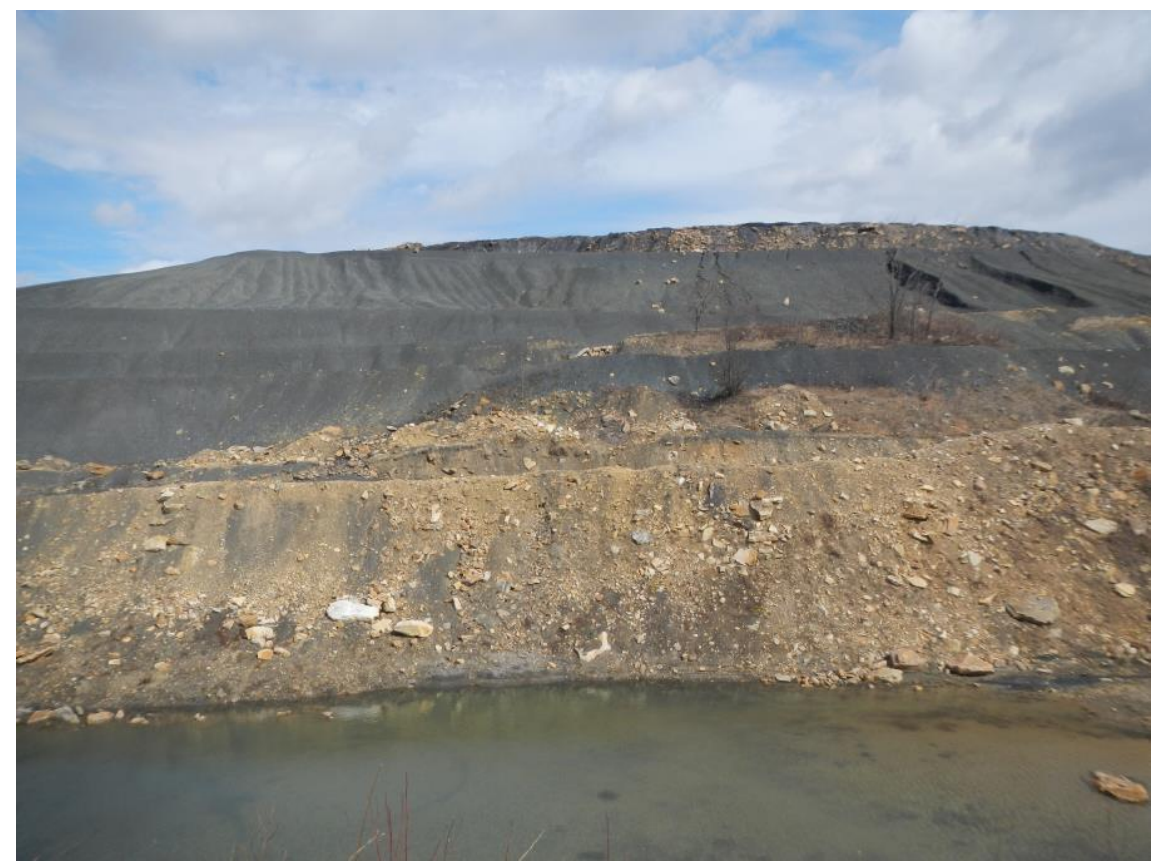

Figure 3. Representative slope face of field site showing no vegetation and presence of erosion features.

\section{$\underline{\text { Design methods }}$}

Site Topography. The following steps were applied to achieve a final design: i) defining the area of disturbance; ii) creating geomorphic watersheds; and iii) balancing the earthwork. Site topography was designed to minimize the need for cut/fill earth movement. Existing topography details (2-ft contour interval) were provided by WVDEP and were used as the basis for the design work (Fig. 4).

Geomorphic watersheds were designed using Carlson Natural Regrade with GeoFluv ${ }^{\mathrm{TM}}$ following guidance from previous work (Sears et al., 2014; DePriest et al., 2015; and Michael et al., 2015). Each watershed included one central channel with perimeter ridgelines. Major design input parameters included: i) maximum distance between connecting channels (10 $\mathrm{ft}$ ); ii) maximum distance from ridgeline to channel head (80 ft); iii) slope at the mouth of the main valley bottom channel (-2\%); iv) drainage density (120 ft/ac); and v) drainage density variance (20\%). The geomorphic watersheds created using Natural Regrade resulted in initial channel pattern and topography. Hillslopes, channel slopes, and channel geometry were then independently adjusted and evaluated to ensure stability as discussed in the following sections. Geomorphic watersheds were connected with conventional bench profiles (maximum bench slopes $=2 \mathrm{H}: 1 \mathrm{~V})$. 
Journal American Society of Mining and Reclamation, 2017 Vol.6, No.1

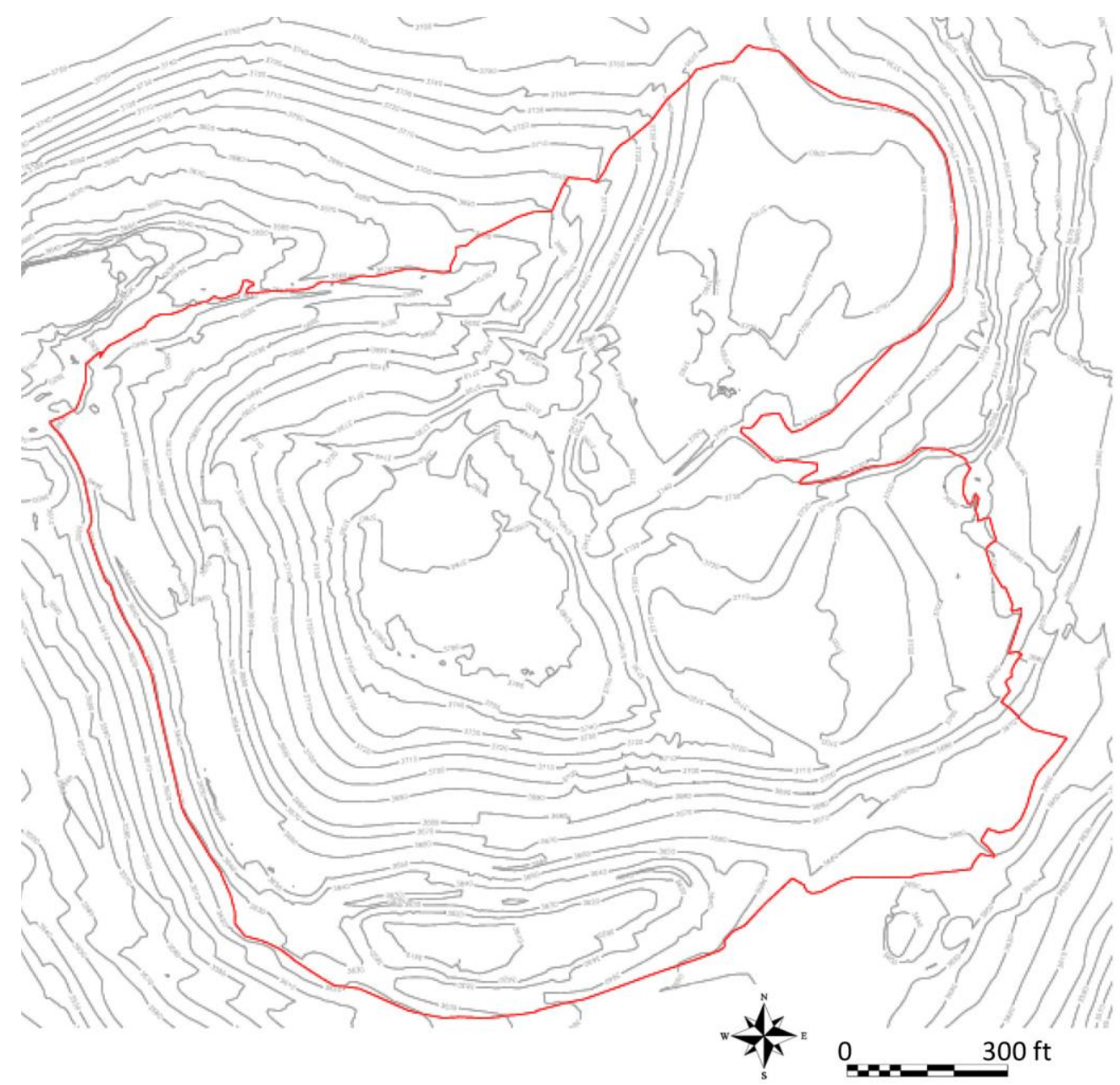

Figure 4. Existing topography of field site (showing 10-ft contours only); red line identifies design area.

The disposal area for the dredged material from the water treatment ponds was contained within the sludge area (Fig. 2). This portion of the site was capped with a layer of compacted, low-permeability refuse and required no excavation. All channelized flow paths were routed around the area.

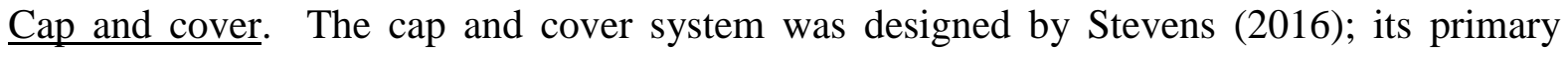
function is to minimize infiltration and sustain vegetation. Geotechnical stability and reduced infiltration were modeled in both saturated and unsaturated seepage infiltration conditions using the SoilVision ${ }^{\mathrm{TM}}$ finite element software. Modeling parameters were obtained from geotechnical laboratory testing of field refuse samples. The field site does not contain suitable growth media, and Stevens (2016) analyzed a short paper fiber residual (MGro ${ }^{\mathrm{TM}}$ ) which is to be blended with the site refuse for a growth layer. $\mathrm{MGro}^{\mathrm{TM}}$ was donated for this research by the WestRock paper 
mill in Covington, Virginia, and is the expected soil amendment to be used at the project site (Stevens, 2016).

Numerical computer modeling for the slopes was completed in the SoilVision Systems TM modeling suite (SVOffice ${ }^{\circledR}$ ) which uses the Finite Element Method (FEM). The program allowed for design and analysis of the conceptual slopes whose geometry, properties, and other features could be easily altered for analysis. The SVSlope ${ }^{\circledR}$ and SVFlux ${ }^{\mathrm{TM}}$ modules of SVOffice ${ }^{\circledR}$ were used to complete the slope stability (factor of safety) and seepage modeling. The modeling included assessing precipitation storm events for both a 4-year average and a 100-year design storm.

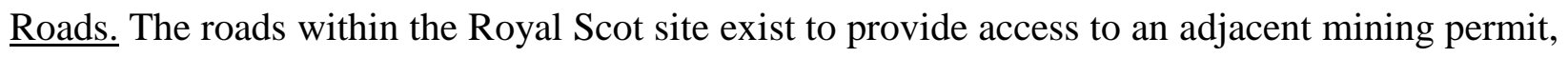
water treatment ponds, and the NPDES discharge point. The roads were altered in elevation and/or alignment as needed to avoid interference with drainage. Access to all mine site areas will be maintained in the proposed design. The site access road was kept to a maximum $10 \%$ grade, with a minimum of $150 \mathrm{ft}$ horizontal radius of curvature which is consistent with the existing road network. A point of departure was defined from the existing structure, and a new road centerline was established conforming to the design standards (WVDEP, 1993). All roads were sloped to eliminate the use of culverts and maintain the existing surface flow paths.

Hydrology and hydraulics. The structures used to control stormwater were designed using the 100yr, 24-hr peak design discharge. The area was analyzed within the WinTR-55 program (NRCS, 2009). A Curve Number of 89 was assumed on all sub-areas indicative of hard-packed coarse coal refuse (Hopkinson et al., 2015) as was used as a conservative value. A precipitation depth of 5.44 in was assumed (NOAA, 2015). Other input values were calculated from the design contours (e.g., watershed area, slope, open channel flow length, sheet flow length).

Centrally draining channels were designed for the geomorphic watersheds. Drainage ditches were designed for the conventional planar slopes, and perimeter channels were designed to route stormwater to a pond. Channel cross-sections and rip-rap lining gradations were designed using methods detailed by Simons et al. (1982) using SEDCAD 4 (Schwab, 2010). The median rip-rap particle size was used to calculate the filter between the channel base material and the flow liner (Simons et al., 1982; Schwab, 2010). A freeboard depth of $0.5 \mathrm{ft}$ was added to both the geomorphic and drainage ditches. A freeboard depth of $1.0 \mathrm{ft}$ was added at the perimeter channels 
(Simons et al., 1982). All surface water was routed to a surface sediment pond that was designed as a dry pond.

\section{$\underline{\text { Results and Discussion }}$}

\section{General site characteristics}

The reclamation design is composed of four geomorphic watersheds (2.8-4.0 acre), each with a centrally draining stream (A, B, C, and D, Fig. 5). The geomorphic watersheds have varying slopes to mimic natural landforms that combine both convex and concave profiles. While there is a range of hillslopes represented in the geomorphic watersheds, all landform slopes are less than or equal to 2:1 as required by design criteria (Fig. 6). An example longitudinal profile comparing the existing and design surface is presented in Fig. 7 for reference. The profile was selected from the center of the pile and extends from the north to the south.

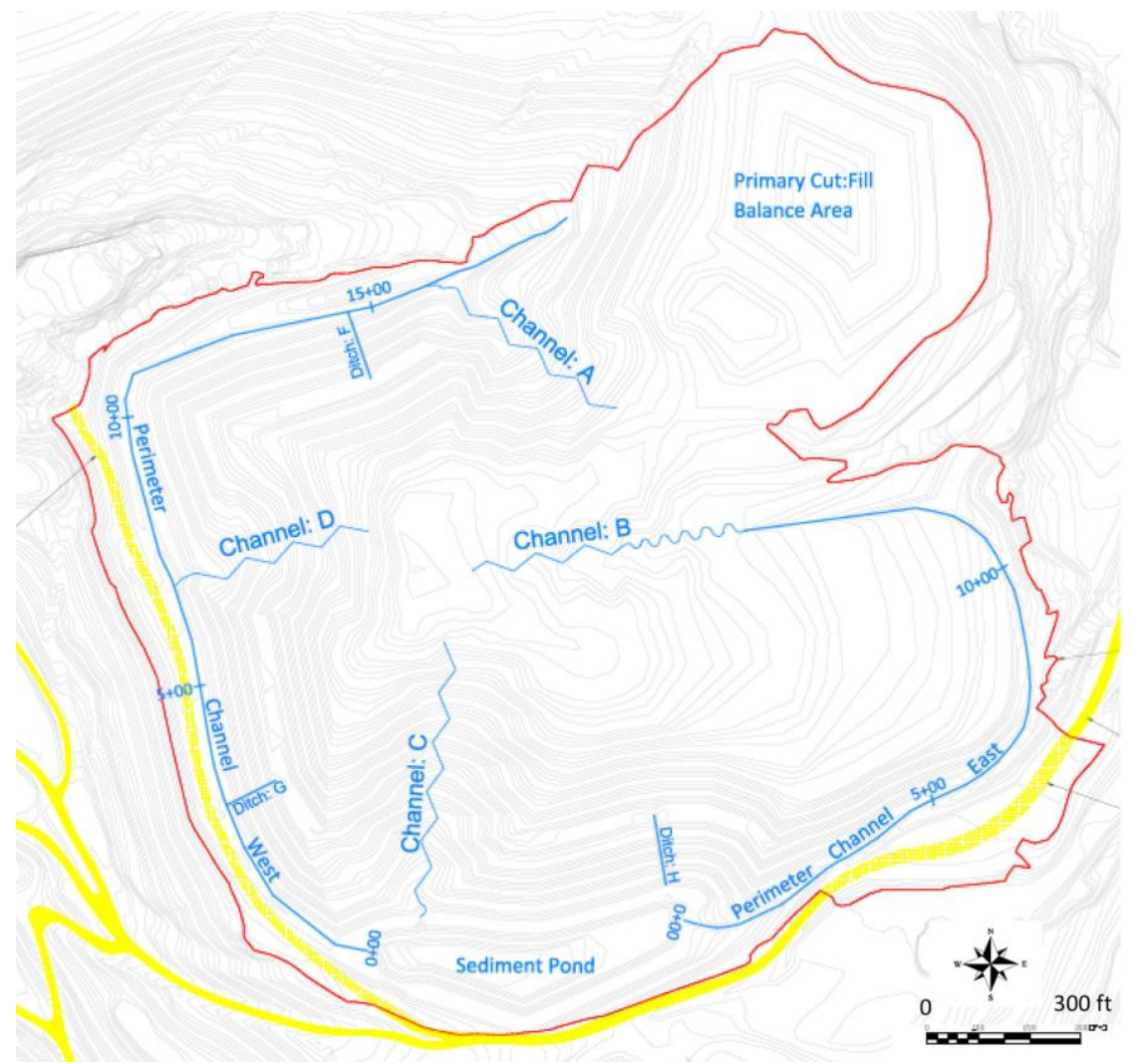

Figure 5. Final design topography (2-ft contours) with placement of four geomorphic channels (A, B, C, and D) three drainage ditches on conventional slopes (F, G, and $\mathrm{H}$ ), perimeter channels (west and east), design boundary (red line), sediment pond, and road network (yellow lines). 


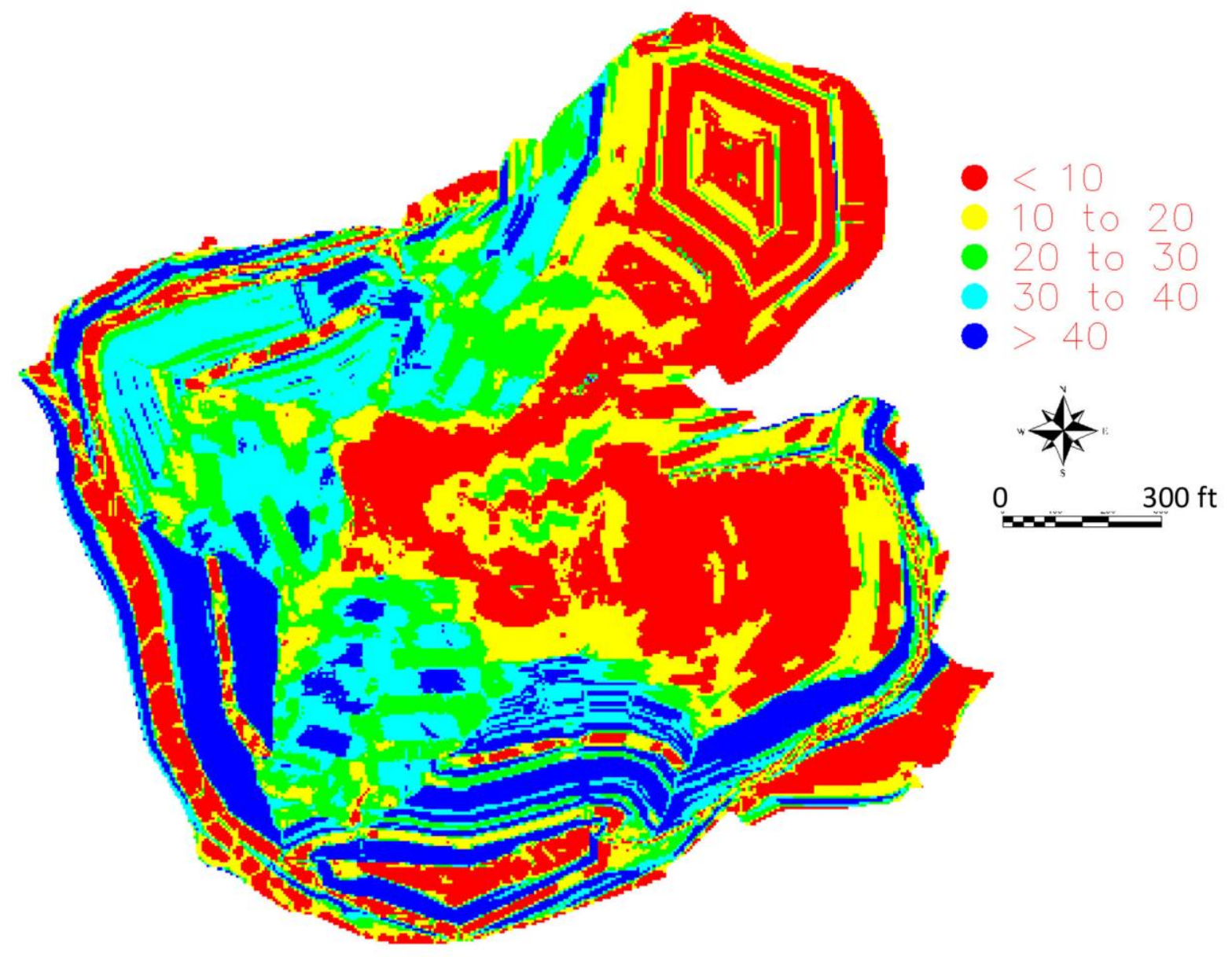

Figure 6. Spatial distribution of landform slope in percent of inclination.

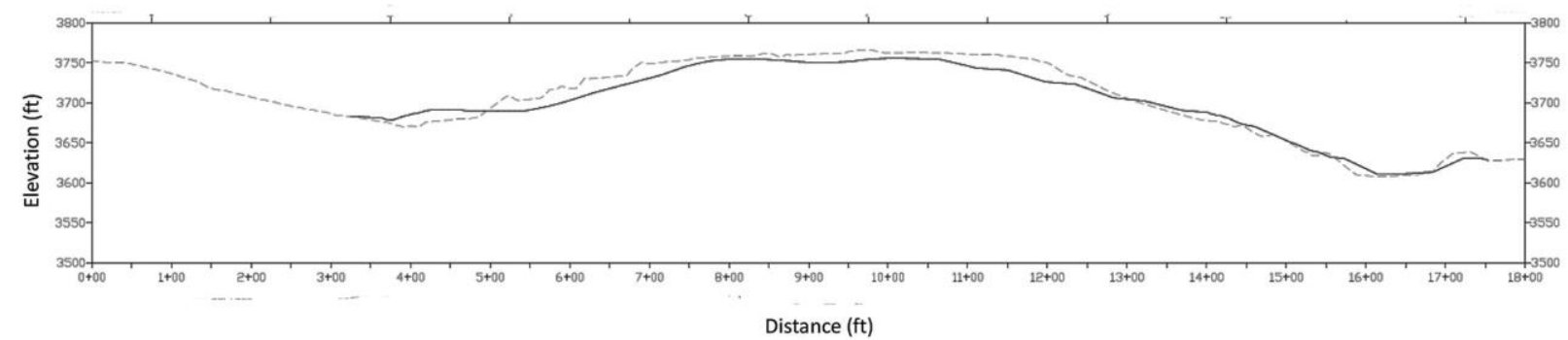

Figure 7. Example longitudinal profile comparing existing (dashed line) and design surface (solid line) through the center of the pile (north to south).

Channels in watersheds A, C, and D have characteristic of headwater streams (e.g. Rosgen channel type A+, Rosgen, 1994). The channels are steep with low sinuosity $(\leq 1.17)$. Watershed B has a gentler slope near the mouth of the channel, so it was designed to have a steep headwater 
section (sinuosity=1.17) flowing into a more sinuous section (Rosgen Channel type C, Rosgen, 1994).

The geomorphic watersheds are connected with conventional benched slopes. Drainage channels $(\mathrm{F}, \mathrm{G}$, and $\mathrm{H})$ were included on the lowest bench in the conventional slopes to promote channelized flow and minimize infiltration into the pile. Hillslopes in the conventional area are also all equal to or less than 2:1 (Fig. 6). The inclusion of conventional slopes was needed to complete the design within the given design area. As stated in the previous section, the design area was bounded by an active permit, treatment ponds, and road infrastructure that prevented increasing the impact area. DePriest et al. (2015) noted that problems with landform and channel stability arise when minimizing the lower grade geomorphic slope which tends to enlarge the site footprint. These issues were addressed in this work by combining both planar slopes with geomorphic watersheds, showing that geomorphic principles can be included as part of a conventional planar-slope profile reclamation plan while minimizing the area of impact.

The reclaimed site drains radially into perimeter channels that direct runoff to a segregated sediment pond. This configuration was chosen in anticipation that the surface water may need some treatment (degassing resulting from the $\mathrm{MGro}^{\mathrm{TM}}$ soil amendment) and to not blend the surface and groundwater. It also allows the pile to drain quickly while not exceeding the capacity of the off-site stream system.

Minimum material excavation transport and borrow material was desired to keep cost competitive with a conventional benched slope design. As such, the geomorphic channels were positioned in locations with naturally occurring gullies, and geomorphic watersheds were areas of cut (Fig. 8). Approximately 21.7 acre of cut $\left(267,731 \mathrm{yd}^{3}\right)$ and 23.4 acre of fill $\left(295,840 \mathrm{yd}^{3}\right)$ were proposed. The excess fill volume accounts for the added amendment proposed in the cap and cover system as discussed in a later section of this paper. The sludge pit was covered by a minimum of $10 \mathrm{ft}$ of material. The maximum cut depth is approximately $30 \mathrm{ft}$ and is located in close proximity to geomorphic channel C. The maximum fill depth is $32 \mathrm{ft}$ and is located above the sludge pit area. 


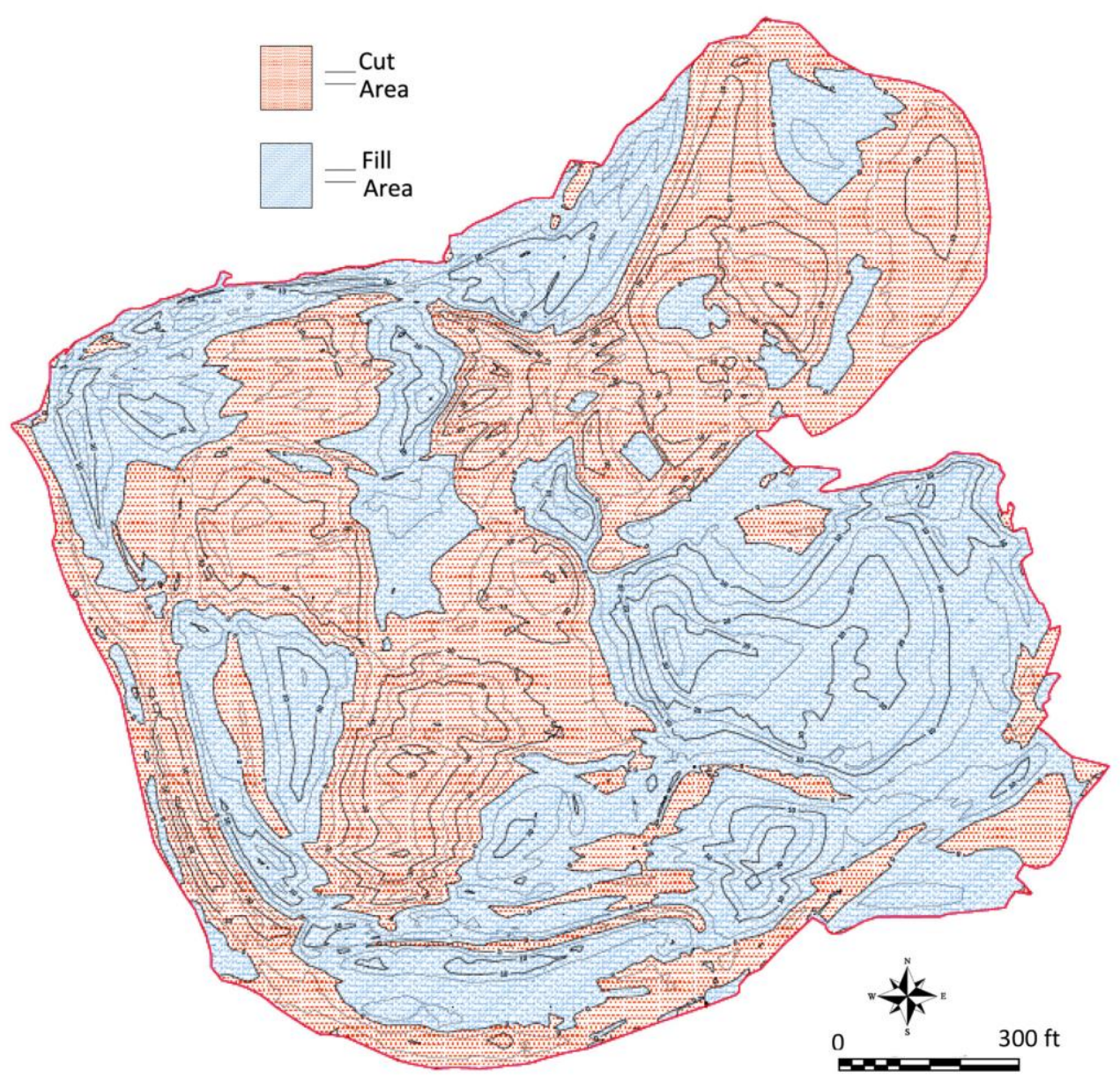

Figure 8. Spatial distribution of cut and fill showing 5-ft cut/fill contours.

$\underline{\text { Hydrology and hydraulics }}$

Capturing the stormwater quickly and concentrating the flow in established channels was considered beneficial to minimizing infiltration. The geomorphic channels (A, B, C, and D) have continuously changing bed slopes and trapezoidal cross sections (Table 1 and Figs. 9 and 10). For ease of construction, two channel cross sections were designed for each channel. Smaller cross sections were designed for the headwater portions of the channel that handle a smaller capacity of flow. Larger cross sections were designed near the channel outlet and were designed at the capacity of the channel outlet. Geomorphic watershed B had a lower valley slope as compared to the other geomorphic watersheds. As such, a portion of the channel was designed to be vegetated rather than rip-rap lined (Table 1). The channels were designed such that a maximum median bed particle size of 12 in was required for stability. A minimum freeboard depth of $0.5 \mathrm{ft}$ was included. 
The drainage ditches were used to remove water from the conventionally designed slopes. The drainage ditches were constructed on the maximum slope of $2: 1$, as the channels flow down the face of the slope (Fig. 10). These channels required a large aggregate size (15-18 in, Table 1). A minimum $0.5 \mathrm{ft}$ freeboard was included into the channel depth.

Two perimeter channels (west and east) flow around the perimeter of the design area. The west channel was designed with a uniform bed slope (0.02) over a length of 1,750 ft. The headwater portion of the channel had a greater slope $(0.15)$ as dictated by the topography. The east channel had bed slopes ranging from 0.06 to 0.10 . Channel bottom widths depths, and median particle size were 7.0-10.5 ft, 1.7-1.8 ft, and 9-12 in, respectively (Table 1).

Table 1. Summary of channel characteristics of geomorphic channels and drainage ditches, and perimeter channels.

\begin{tabular}{|c|c|c|c|c|c|c|c|}
\hline Reach & Liner & $L(\mathrm{ft})$ & $b(\mathrm{ft})$ & $h(\mathrm{ft})$ & $S$ (slope) & Bed $D_{50}$ & Filter $D_{50}$ \\
\hline \multicolumn{8}{|c|}{ Geomorphic channels } \\
\hline A & Rip-rap & 513 & $5.0-6.0$ & $0.6-0.8$ & $0.12-0.20$ & 9 & 3 \\
\hline $\mathrm{B}$ & Vegetated & 475 & 4.5 & 2.3 & $0.02-0.03$ & $*$ & $*$ \\
\hline $\mathrm{B}$ & Rip-rap & 257 & $3.5-4.0$ & $0.7-0.9$ & $0.04-0.12$ & 9 & 3 \\
\hline $\mathrm{C}$ & Rip-rap & 622 & $4.0-6.0$ & $0.6-0.8$ & $0.12-0.24$ & 12 & 3 \\
\hline $\mathrm{D}$ & Rip-rap & 514 & $4.5-5.5$ & $0.6-0.8$ & $0.12-0.27$ & 12 & 3 \\
\hline \multicolumn{8}{|c|}{ Conventional ditches } \\
\hline $\mathrm{F}$ & Rip-rap & 155 & 4.0 & 1.1 & 0.5 & 18 & 3 \\
\hline $\mathrm{G}$ & Rip-rap & 160 & 2.0 & 1.1 & 0.5 & 18 & 3 \\
\hline $\mathrm{H}$ & Rip-rap & 130 & 3.5 & 1.1 & 0.5 & 15 & 3 \\
\hline \multicolumn{8}{|c|}{ Perimeter channels } \\
\hline West & Rip-rap & 2270 & $7.0-10.5$ & 1.8 & $0.02-0.15$ & 9 & 3 \\
\hline East & Rip-rap & 1492 & 8.0 & 1.7 & $0.06-0.1$ & $9-12$ & 3 \\
\hline
\end{tabular}

*Grass-lined 


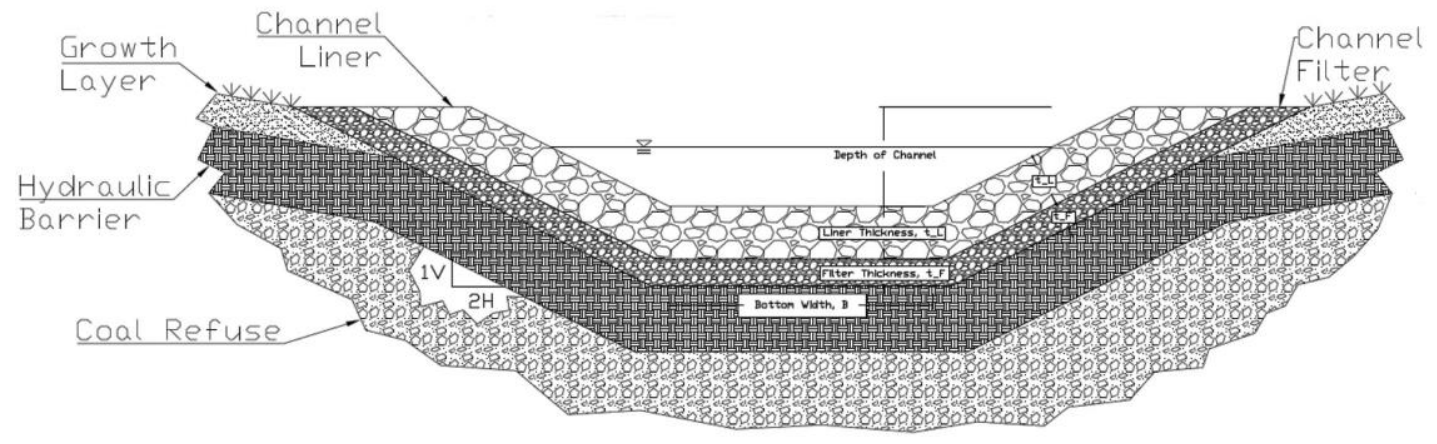

Figure 9. Typical channel cross section of rip-rap channels.

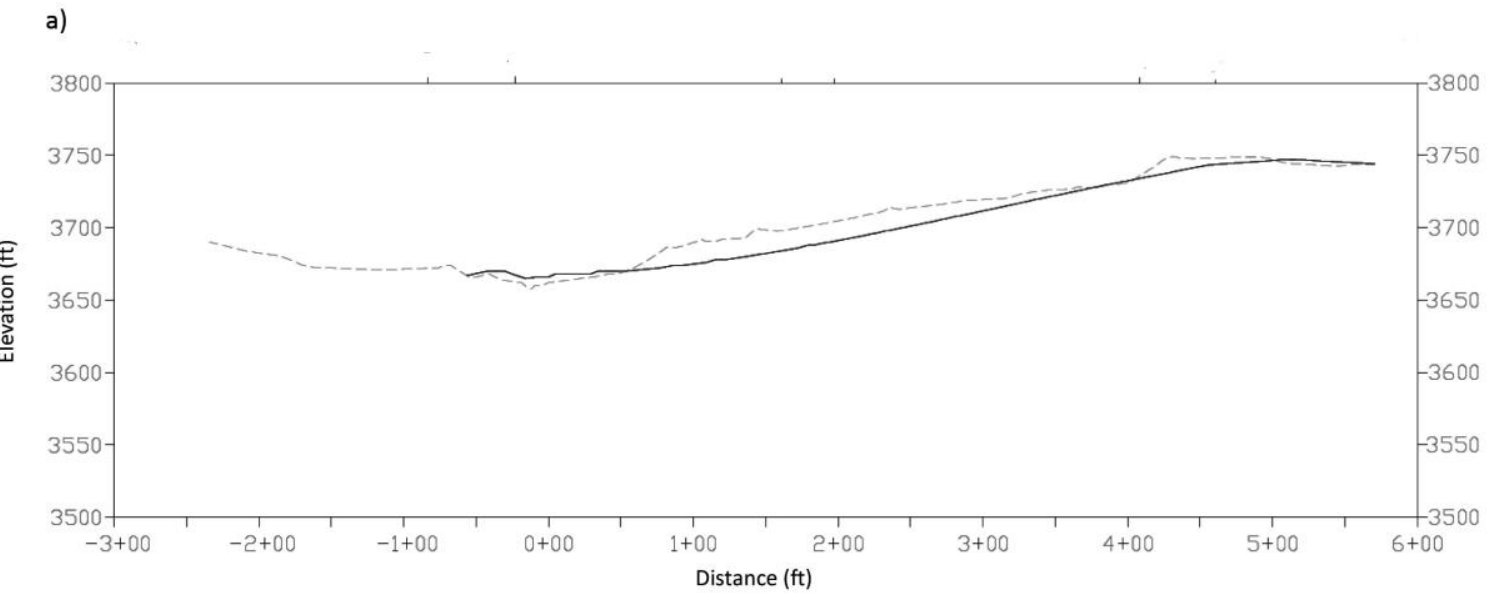

b)

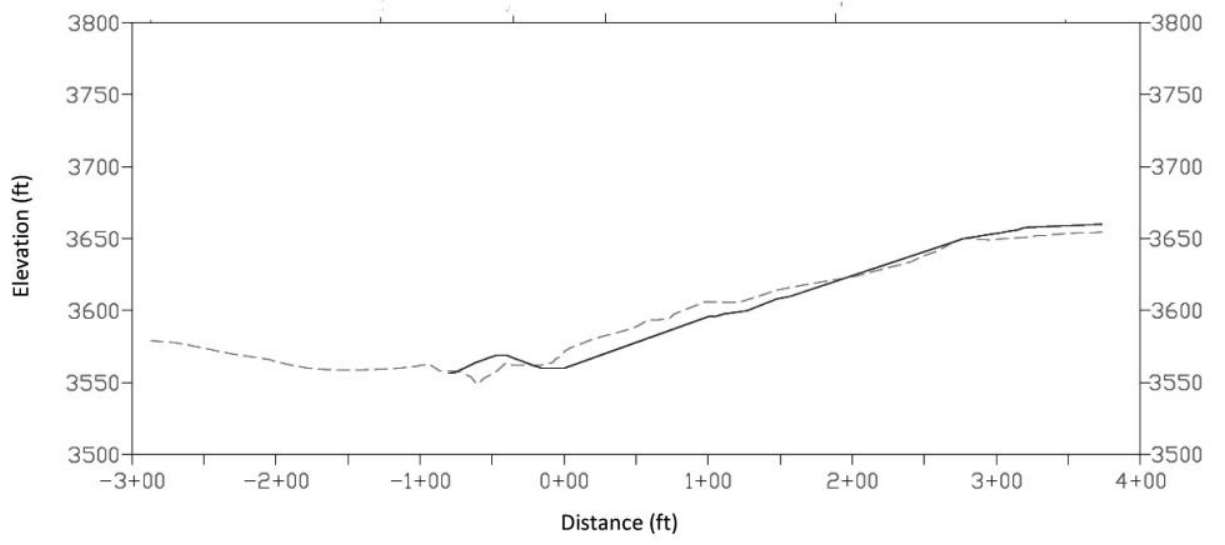

Figure 10. Example channel longitudinal profiles: a) geomorphic channel A and b) drainage ditch $\mathrm{F}$ (dashed line=existing surface; solid line=design surface). 


\section{Cap and cover system.}

The cap and cover system is to be applied to the entire affected area of the reclamation site. The function of this two-layer system is to decrease infiltration and facilitate growth of vegetation using the $\mathrm{MGro}^{\mathrm{TM}}$ as an agricultural amendment. The top layer of the system is a growth layer composed of a volumetric ratio with $60 \%$ coal refuse blended with $40 \%$ MGro $^{\mathrm{TM}}$ paper fiber residual. The blend ratio as well as the depth (12 in) of the growth layer was determined by considering results of stability/seepage modeling, needed growth depth, and cost. The bottom layer is a hydraulic low permeability zone designed using unsaturated soil mechanics principals and constructed using compacted coarse coal refuse. The thickness of the low permeability zone was set to range between 1-2 feet depending on slope application requirements (Fig. 11). Generally, a 2-ft layer was recommended for the geomorphic areas, and a 1-ft layer was recommended for the planar slopes. The geomorphic slope maintains a higher geotechnical factor of safety for both the average and 100-year design storm boundary conditions. Both the geomorphic and conventional benched slopes meet or exceed the 1.5 minimum factor required by the West Virginia DEP for the project.
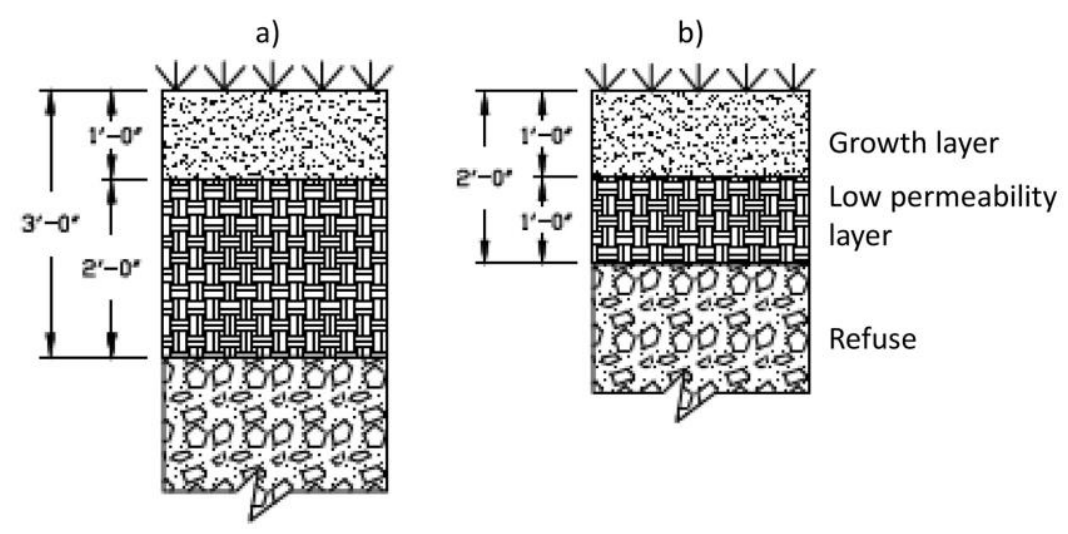

Figure 11. Two-layer cap and cover system for a) geomorphic areas and b) conventional steep-slope areas

\section{Conclusions}

Geomorphic landforming principles were demonstrated in southern West Virginia on a ridgetop coarse coal refuse pile. The geomorphic reclamation plan accomplished the following design objectives:

1. Apply geomorphic landforming principles: This work shows that there was the potential to apply geomorphic reclamation even in small disturbance areas. Four geomorphic areas 
were established with continuously changing slope profiles and center draining streams. The original intent was to apply geomorphic reclamation to the entire site. Due to site specific characteristics (allowable design area, amount of material, etc.), geomorphic reclamation was combined with conventional, benched methods.

2. Reduce stormwater infiltration: Engineered cap systems were designed and applied to minimize infiltration. The stormwater was directed to engineered channels quickly to minimize contact time with the refuse.

3. Segregate stormwater and groundwater flows: The stormwater and groundwater systems are now separated. The stormflow was directed in channels and ditches to a sediment pond. The groundwater will continue to be directed to the existing treatment ponds.

4. Minimize earthmoving quantities: The location of the channels and placement of the geomorphic watersheds was directed to locations where there are naturally occurring gullies. The attempt was to drain toward current gullies and make them permanent channels to reduce the earth movement needed to complete the design.

5. Minimize import material: Onsite material was used throughout the design. Sandstone was available for the channel liner and channel filter material. The coal refuse was used in the two-layer cap design. The refuse was mixed with the soil amendment, MGro ${ }^{\mathrm{TM}}$ to make the growth layer, and the hydraulic low-permeability layer was designed of compacted refuse material. The inclusion of the soil amendment was a novel approach to maximize the amount of onsite materials used in the growth zone. The amendment decreased the need to create topsoil to cover the site.

Successful field application of the proposed design will provide an opportunity for government agencies to assess the future of geomorphic landforming in Central Appalachia. Geomorphic landforming principles have the potential to be applied in various sectors such as mining, municipal landfills, dams, large scale commercial development, and transportation projects. Many similar abandoned sites exist throughout the region, and the results from this work have the potential to influence future reclamation and landforming activities. 


\section{Acknowledgements}

The work described in this publication was supported by Grant/Cooperative Agreement Number S15AC20020 from the Office of Surface Mining. Its contents are solely the responsibility of the authors and do not necessarily represent the official views of the OSMRE. This work is also in collaboration with the West Virginia Department of Environmental Protection. The authors would like to thank Mr. Greg Cox at WestRock for donating the MGro ${ }^{\mathrm{TM}}$ used in this project. The authors would like to thank Mike Sheehan, Nathan Parks, Dave McCoy, Jason Fox, and Mike Richardson for their continued support.

\section{$\underline{\text { Literature Cited }}$}

DePriest, N.C., L.C. Hopkinson, J.D. Quaranta, P.R. Michael, and P.F. Ziemkiewicz. 2015. Geomorphic landform design alternatives for an existing valley fill in central Appalachia, USA: Quantifying the key issues. Ecological Engineering 81: 19-29. https://doi.org/10.1016/j.ecoleng.2015.04.007

Eckels, R. and N. Bugosh 2010. Natural approach to mined land reclamation. FIG Congress Sydney, Australia, 11-16 April 2010.

Hancock, G.R., R. Lock, and G.R. Willgoose. 2003. The design of post-mining landscapes using geomorphic guidelines. Earth Surface Processes and Landforms 28(1): 1097-1110. https://doi.org/10.1002/esp.518

Hopkinson, L.C., A.E. Sears, M. Snyder, E. O’Leary, N. DePriest, J.D. Quaranta, and P.F. Ziemkiewicz. 2015. Simulating the hydrologic response when streams are incorporated in valley-fill design. International Journal of Mining, Reclamation and Environment 30: 422-437. https://doi.org/10.1080/17480930.2015.1105180

Martin-Duque, J.F., M.A. Sanz, J.M. Bodoque, A. Lucia, and C. Martin-Moreno. 2010. Restoring earth surface processes through landform design. A 13-year monitoring of a geomorphic reclamation model for quarries on slopes. Earth Surface Processes and Landforms 35: 531548. https://doi.org/10.1002/esp.1950

Measles D. and N. Bugosh N. 2007. Making and building a fluvial geomorphic reclamation design at an active dragline mine using the GeoFluv® design method. 30 Years of SMCRA and 
Beyond, Proceedings America Society of Mining and Reclamation, 2007 pp 449-456 https://doi.org/10.21000/JASMR07010449

Michael, P., M. Superfesky, and L. Uranoswki. 2010. Challenges of applying geomorphic and stream reclamation methodologies to mountaintop mining and excess spoil fill construction in steep slope topography (e.g. central Appalachia). Proceedings American Society of Mining and Reclamation, 2010 pp 610-634. https://doi.org/10.21000/JASMR10010610

Michael, P.R., L.C. Hopkinson, N. DePriest, and J.D. Quaranta. 2015. Methodology for applying geomorphic reclamation to excess spoil fills in West Virginia. Journal of the American Society of Mining and Reclamation 4(2): 57-72. https://doi.org/10.21000/JASMR15010057

National Oceanic and Atmospheric Administration (NOAA). 2015. Precipitation Frequency Data Server (PFDS). Hydrometeorological Design Studies Center. http://hdsc.nws.noaa.gov (accessed 5 Oct. 2015).

National Resource Conservation Service (NRCS). 2009. Small Watershed Hydrology, WinTR-55. United Stated Department of Agriculture, Conservation Engineering Division. United States.

Robson, M., R. Spots, R. Wade, and W. Erickson. 2009. A case history: Limestone quarry reclamation using fluvial geomorphic design techniques. Proceedings American Society of Mining and Reclamation. 2009 pp 1166-1175. https://doi.org/10.21000/JASMR09011166

Rosgen, D.L. 1994. A classification of natural rivers. Catena 22(3): 169-199. https://doi.org/10.1016/0341-8162(94)90001-9

Schor, H.J. and D.H. Gray. 2007. Landforming: An Environmental Approach to Hillside Development, Mine Reclamation and Watershed Restoration. John Wiley \& Sons, New Jersey. https://doi.org/10.1002/9780470259900

Schwab, P.J. 2010. SEDCAD 4. SEDCAD 4 for Windows (CD-ROM/USB Drive), Civil Software Design Ames, Iowa.

Sears, A., C.J. Bise, J.D. Quaranta, and L.C. Hopkinson. 2014. Field and modeling study for stream mitigation on surface mine sites in West Virginia. Transactions of the Society for Mining, Metallurgy, and Exploration 336: 64-69. 
Simons D.B., R.M. Li, J.D., Schall, M.R. Peterson, B.A. Anderson, R.M. Summer, and W.T. Fullerton. 1982. Surface Mining Diversion Design Manual. US Department of the Interior, Office of Surface Mining. OSMRE/TR-82/2.

Stevens, J.R. 2016. Geotechnical Testing and Finite Element Modeling of Geomorphic Landform Design with a Multi-Layer Cap and Cover System. M.S. thesis, West Virginia University, Morgantown.

Toy, T.J. and W.R. Chuse. 2005. Topographical reconstruction: A geomorphic approach. Ecological Engineering 24: 29-35. https://doi.org/10.1016/j.ecoleng.2004.12.014

U.S. Environmental Protection Agency (USEPA). 2013. Level III ecoregions of the continental United States: Corvallis, Oregon, U.S. EPA - National Health and Environmental Effects Research Laboratory, map scale 1:7,500,000. https://www.epa.gov/eco-research/level-iii-andiv-ecoregions-continental-united-states (accessed 25 Oct. 2016).

Ward, K. 2001. A toxic legacy. Charleston Gazette-Mail. www.wvgazettemail.com/News/MiningtheMountains/200108120003 (accessed 20 April 2017)

West Virginia Department of Environmental Protection (WVDEP). 1993. Technical Handbook: Standards and Specifications for Erosion and Sediment Control Excess Spoil Disposal Haulageways. WV Department of Environmental Protection, Washington, DC. 